\title{
REPRESENTASI ADEGAN KEKERASAN DALAM TAYANGAN KOMEDI TELEVISI (ANALISIS SEMIOTIKA TERHADAP PROGRAM OPERA VAN JAVA DI TRANS7)
}

\author{
Endah Fantini \\ Institut Ilmu Sosial dan Manajemen Stiami \\ Email : endah_fantini@yahoo.com
}

\begin{abstract}
ARTIICLE INFO
ABSTRACT

Keywords:

violent scene

representation, Opera Van

Java comedy show,

Semiotics

Opera Van Java (OVJ) Television program on Trans 7 earns a high rating and share in a relatively short time. This is a new phenomenon in the category of comedy that shows a television program in Indonesia can be successful. This event received much praise, so the OVJ included a comedy that received great public attention. The silly story presented by OVJ is very funny and appealing to all walks of life.

Trans7's communications management on this television comedy program has demonstrated professional work in managing comedy programs. This is done by building the synergy / performance of all the crew, communicating creative ideas and ideas, equating perceptions, packing messages and impressions. This process creates an OVJ program that appeals to the audience and can convey messages to all walks of life and age.

The Trans7 OVJ program got the highest rating and share of the comedy version according to AGB Nielsen measurement by Audiences Meansurement version. This assessment is very influential, because the OVJ program is a phenomenal comedy that will increase advertising revenue as a source of income Trans 7 television stations.

Creativity in communication management Opera Van Java (OVJ) is packaged in such a way that it is always interesting to watch on every episode. Researchers found and saw great creativity in the OVJ program. The conclusion is that good communication management in managing television comedy programs is essential to improve the rating and share of the program.
\end{abstract}

\section{PENDAHULUAN}

Media massa (sebagai suatu bentuk komunikasi massa) mewarisi fungsi dari komunikasi massa, yaitu memberikan sarana kepada masyarakat untuk mengambil keputusan dan membentuk opini kolektif yang bisa digunakan untuk bisa memahami diri mereka sendiri dan lingkungan sekitarnya. Media massa adalah mata dan telinga bagi masyarakat. (Werner, J dan James W. Tankard,2001)

Tayangan komedi merupakan salah satu pilihan hiburan untuk sekadar melepas stress. Ditinjau arti dari komedi itu merupakan salah satu bentuk berhumor. Opera Van Java (OVJ) merupakan tayangan komedi yang berhasil membuat sebagian besar penontonnya setia menonton. Format OVJ seperti pementasan wayang orang yang lengkap dengan dalang, sinden dan para pemain gamelan. Cerita-cerita yang dibawakan tidak hanya seputar legenda maupun cerita rakyat lokal, tapi juga berasal dari cerita film, gosip selebriti sampai fiksi yang memang dibuat dengan tema kehidupan sehari-hari. Segala hal konyol dilakukan oleh para pemainnya untuk membuat penonton tertawa. Satu hal yang menjadi ciri khas lawakannya adalah penggunaan properti styrofoam. Properti ini menjadi andalan mereka untuk menciptakan tawa dari penontonnya. Bisa dengan cara mendorong salah satu pemain hingga dia terjatuh menimpa properti, memukulkan properti tersebut pada pemain lainnya, dan masih banyak lagi. Tak hanya itu, cara mereka membuat lawakan pun tidak lepas dari ejekan para pemainnya. Adegan-adegan seperti inilah yang menjadi sorotan dalam model perencanaan pemecahan masalah kekerasan dalam tayangan komedi Opera Van Java (OVJ) di Trans7. Ide cerita yang berbeda dengan tayangan komedi sebelum-sebelumnya menciptakan hal baru yang digemari pemirsanya. Dengan tampilan wayang orang, OVJ mampu membuat para penontonnya 
puas tertawa oleh tingkah polah para pemainnya. OVJ membuktikan kejayaannya di Panasonic Gobel Awards ke 13 kemarin dengan berhasil meraih satu penghargaan sebagai program komedi terfavorit.

Penelitian ini dilakukan dengan latar belakang bahwa tayangan Opera Van Java yang pada awal penayangannya berkomitmen untuk tidak hanya menghibur tapi juga memberikan pendidikan melalui ceritacerita rakyat yang disajikan, ternyata dalam praktiknya malah menonjolkan kekerasan sebagai bahan lelucon. Tayangan komedi yang mengusung konsep pewayangan ini berhasil meraih rating tinggi dengan lelucon slapstick yang ditampilkannya. Kekerasan baik secara fisik maupun verbal dijadikan alat untuk memancing tawa penonton. Padahal penonton tak hanya datang dari kalangan dewasa saja, tapi juga anak-anak yang rentan melakukan tindakan imitasi. Karena itu,penelitian ini mencoba untuk mengetahui bagaimana naturalisasi terhadap tindak kekerasan yang dilakukan dalam tayangan komedi OVJ?

Sesuai dengan masalah yang dirumuskan, tujuan penelitian ini adalah sebagai berikut :

-Untuk menganalisis representasi kekerasan dalam tayangan komedi OVJ

-Untuk mengetahui naturalisasi suatu tindak kekerasan yang dilakukan dalam tayagan komedi OVJ, serta nilai dominan yang ditampilkan dalam adegan kekerasan pada tayangan komedi tersebut.

\section{KAJIAN PUSTAKA}

Dalam sebuah tayangan komedi yang menjadi objek penelitian ini mengandung kode-kode yang dapat kita baca dengan menggunakan sebuah analisis. Untuk membaca kode-kode tersebut, kita dapat menggunakan teknik analisis cultural studies dari John Fiske seperti dalam bukunya "Television Culture" (1992). Dalam hal ini tayangan komedi, di mana tayangan komedi dalam prakteknya memproduksi tandatanda.

Level pertama :

"Realitas"

Penampilan, busana, make-up, environment (lingkungan), behavior (kelakuan), speech (cara berbicara), gesture (bahasa tubuh), ekspresi. Semua dibentuk secara elektonik oleh kode-kode.

Level kedua :

"Representasi"

Kamera, lighting (tata cahaya), editing, musik, sound

Sebagai pengirim conventional representational codes (kode-kode

representasi yang umum), yang mana merupakan bentuk dari representations, sebagai

contoh :

Cerita, konflik, karakter, dialog, setting, dan lain-lain.

Level ketiga :

"Ideologi"

Disusun kedalam hubungan dan diterima secara social

oleh ideological codes (kode-kode ideologi), seperti :

Individualisme, patriarki, ras, kelas (penggolongan berdasar kelas sosial),

materialisme, kapitalisme, dan lain-lain. (Fiske, 1992: 5)

Adapun teori lain yang mendukung penelitian ini adalah :

\section{Teori Perbedaan Individu ( Individual Differences Theory)}

Asumsi teori ini adalah pesan-pesan yang disampaikan media massa ditangkap individu sesuai dengan karakteristik dan kebutuhan personal individu. Efek komunikasi pada individu akan beragam walaupun individu menerima pesan yang sama. Terdapat faktor psikologis dalam menerima pesan yang disampaikan media massa. Masing-masing individu mempunyai perhatian, minat, keinginan yang berbeda yang dipengaruhi faktor-faktor psikologis yang ada pada diri individu tersebut sehingga mempengaruhi dalam menerima pesan yang disampaikan media massa.

Teori Penggolongan Sosial (Social Category Theory)

Asumsi teori ini adalah individu yang masuk dalam kategori sosial tertentu atau sama akan cenderung memiliki prilaku atau sikap yang kurang lebih sama terhadap rangsangan-rangsangan tertentu. Pesan-pesan yang disampaikan media massa cenderung ditanggapi sama oleh individu yang termasuk dalam kelompok sosial tertentu

Penggolongan sosial ini berdasarkan :

Usia : anak-anak, dewasa, orangtua 
Jenis kelamin

: laki-laki, perempuan

Suku bangsa

: Sunda, Jawa, Batak, Minang, Aceh, Papua, Bali, dan lainnya.

Profesi

Pendidikan

: dokter, pengusaha, pedagang, sopir, tukang becak, dan lainnya.

Kegemaran atau hobby : Olahraga, kesenian, dan lainnya.

Status sosial

: Kaya, biasa, dan miskin.

Agama

: Islam, Kristen,Hindu, Budha, Konghucu, dan lainnya.

Teori Norma Budaya ( Norm and Cultural Theory)

Asumsi teori ini adalah media massa melalui informasi yang disampaikannya dengan cara-cara tertentu dapat menimbulkan kesan yang oleh khalayak disesuaikan dengan norma-norma dan nilai-nilai budayanya. Media massa mempengaruhi budaya-budaya masyarakatnya dengan cara pesan-pesan yang disampaikan media massa memperkuat budaya yang ada.Ketika suatu budaya telah kehilangan tempat apresiasinya, kemudian media massa memberi lahan atau tempat maka budaya yang pada awalnya sudah mulai luntur menjadi hidup kembali. Media massa telah menciptakan pola baru tetapi tidak bertentangan. Media massa mengubah budaya lama dengan budaya baru yang berbeda dengan budaya lama. Contoh : Terdapat acaraacara tertentu yang bukan tak mungkin lambat laun akan menumbuhkan budaya baru, seperti acara Opera Van Java (OVJ).

Teori Pengaruh Tradisi (The Effect Tradition)

Teori pengaruh komunikasi massa dalam perkembangannya telah mengalami perubahan yang kelihatan berliku-liku dalam abad ini. Dari awalnya, para peneliti percaya pada teori pengaruh komunikasi "peluru ajaib" (bullet theory) Individu-individu dipercaya sebagai dipengaruhi langsung dan secara besar oleh pesan media, karena media dianggap berkuasa dalam membentuk opini public. Sehingga pada saat itu pengaruh media dianggap terbatas (limited-effectsmodel).

Sekarang setelah riset di tahun 1970-an dan 1980-an, banyak ilmuwan komunikasi sudah kembali ke powerful-effects model, di mana media dianggap memiliki pengaruh yang kuat, terutama media televisi.Ahli komunikasi massa yang sangat mendukung keberadaan teori mengenai pengaruh kuat yang ditimbulkan oleh media massa adalah Noelle-Neumann melalui pandangannya mengenai gelombang kebisuan.

Teori Pengharapan Nilai (The Expectacy-Value Theory)

Phillip Palmgreen berusaha mengatasi kurangnya unsur kelekatan yang ada di dalam teori uses and gratification dengan menciptakan suatu teori yang disebutnya sebagai expectance-value theory (teori pengharapan nilai). Dalam kerangka pemikiran teori ini, kepuasan yang Anda cari dari media ditentukan oleh sikap Anda terhadap media --kepercayaan Anda tentang apa yang suatu medium dapat berikan kepada Anda dan evaluasi Anda tentang bahan tersebut. Sebagai contoh, jika Anda percaya bahwasituated comedy (sitcoms), seperti Bajaj Bajuri menyediakan hiburan dan Anda senang dihibur, Anda akan mencari kepuasan terhadap kebutuhan hiburan Anda dengan menyaksikan sitcoms. Jika, pada sisi lain, Anda percaya bahwa sitcoms menyediakan suatu pandangan hidup yang tak realistis dan Anda tidak menyukai hal seperti ini Anda akan menghindari untuk melihatnya.

Teori Ketergantungan (Dependency Theory)

Teori ketergantungan terhadap media mula-mula diutarakan oleh Sandra Ball-Rokeach dan Melvin Defleur. Seperti teori uses and gratifications, pendekatan ini juga menolak asumsi kausal dari awal hipotesis penguatan. Untuk mengatasi kelemahan ini, pengarang ini mengambil suatu pendekatan sistem yang lebih jauh. Di dalam model mereka mereka mengusulkan suatu relasi yang bersifat integral antara pendengar, media. dan sistem sosial yang lebih besar.

Sejalan dengan apa yang dikatakan oleh teori uses and gratifications, teori ini memprediksikan bahwa khalayak tergantung kepada informasi yang berasal dari media massa dalam rangka memenuhi kebutuhan khalayak bersangkutan serta mencapai tujuan tertentu dari proses konsumsi media massa. Namun perlu digarisbawahi bahwa khalayak tidak memiliki ketergantungan yang sama terhadap semua media.

Ada dua jawaban mengenai melandasi ketergantungan khalayak terhadap media massa. Pertama, khalayak akan menjadi lebih tergantung terhadap media yang telah memenuhi berbagai kebutuhan khalayak bersangkutan dibanding pada media yang menyediakan hanya beberapa kebutuhan saja. Sumber ketergantungan yang kedua adalah kondisi sosial. Model ini menunjukkan sistem media dan institusi sosial itu saling berhubungan dengan khalayak dalam menciptakan kebutuhan dan minat. Pada gilirannya hal ini akan mempengaruhi khalayak untuk memilih berbagai media, sehingga bukan sumber media massa yang 
menciptakan ketergantungan, melainkan kondisi sosial. Untuk mengukur efek yang ditimbulkan media massa terhadap khalayak, ada beberapa metode yang dapat digunakan, yaitu riset eksperimen, survey dan riset etnografi.

Uses and Gratifications Theory

Teori kegunaan dan kepuasan memandang pengguna media mempunyai kesempatan untuk menentukan pilihan-pilihan media sumber beritanya. Dalam hal ini, pengguna media berperan aktif dalam kegiatan komunikasi untuk memenuhi kepuasannya. Teori ini mempertimbangkan apa yang dilakukan orang pada media, yaitu menggunakan media untuk pemuas kebutuhannya. Penganut teori ini meyakini bahwa individu sebagai mahluk supra-rasional dan sangat selektif. Menurut para pendirinya, Elihu Katz;Jay G. Blumler; dan Michael Gurevitch (dalam Jalaluddin Rakhmat, 1984), uses and gratifications meneliti asal mula kebutuhan secara psikologis dan sosial, yang menimbulkan harapan tertentu dari media massa atau sumber-sumber lain , yang membawa pada pola terpaan media yang berlainan (atau keterlibatan pada kegiatan lain), dan menimbulkan pemenuhan kebutuhan dan akibat-akibat lain.

Perkembangan teori Uses and Gratification Media dibedakan dalam tiga fase (dalam Rosengren dkk., 1974), yaitu:

1. Fase pertama ditandai oleh Elihu Katz dan Blumler (1974) memberikan deskripsi tentang orientasi subgroup audiens untuk memilih dari ragam isi media. Dalam fase ini masih terdapat kelemahan metodologis dan konseptual dalam meneliti orientasi audiens.

2. Fase kedua, Elihu Katz dan Blumler menawarkan operasionalisasi variabel-variabel sosial dan psikologis yang diperkirakan memberi pengaruh terhadap perbedaan pola-pola konsumsi media. Fase ini juga menandai dimulainya perhatian pada tipologi penelitian gratifikasi media.

3. Fase ketiga, ditandai adanya usaha menggunakan data gratifikasi untuk menjelaskan cara lain dalam proses komunikasi, dimana harapan dan motif audiens mungkin berhubungan.

Kristalisasi dari gagasan, anggapan, temuan penelitian tentang Uses and Gratification Media mengatakan, bahwa kebutuhan social dan psikologis menggerakkan harapan pada media massa atau sumber lain yang membimbing pada perbedaan pola-pola terpaan media dalam menghasilkan pemuasan kebutuhan dan konsekuensi lain yang sebagian besar mungkin tidak sengaja.

Elihu Katz;Jay G. Blumler; dan Michael Gurevitch (dalam Baran dan Davis, 2000) menguraikan lima elemen atau asumsi-asumsi dasar dari Uses and Gratification Media sebagai berikut:

1. Audiens adalah aktif, dan penggunaan media berorientasi pada tujuan.

2. Inisiative yang menghubungkan antara kebutuhan kepuasan dan pilihan media spesifik terletak di tangan audiens

3. Media bersaing dengan sumber-sumber lain dalam upaya memuaskan kebutuhan audiens

4.Orang-orang mempunyai kesadaran-diri yang memadai berkenaan penggunaan media, kepentingan dan motivasinya yang menjadi bukti bagi peneliti tentang gambaran keakuratan penggunaan itu.

5.Nilai pertimbangan seputar keperluan audiens tentang media spesifik atau isi harus dibentuk.

\section{Teori kategori sosial}

Kumpulan, kelompok, atau kategori-kategori sosial yang ada di masyarakat akan memberikan tanggapan yang seragam terhadap terpaan media.

Teori Peluru atau Teori Hypodermic

Media amat sangat berpengaruh dan dampaknya cepat seperti peluru atau jarum suntik hypodermic.

Teori Pembelajaran Sosial (Social Learning Theory)

Teori ini menjelaskan bahwa pemirsa meniru apa yang mereka lihat di media sebagai proses observational learning

Teori Kultivasi adalah teori ini berpendapat bahwa terpaan media massa menanamkan pandangan tentang dunia yang secara konsisten menghadirkan "kenyataan"

Priming adalah teori ini menyatakan bahwa stimulasi gambaran media berhubungan dengan apa yang ada di pikiran khalayak.

Bila ditinjau dari penelitian terdahulu, pada dasarnya penelitian studi kasus tentang manajemen komunikasi sudah banyak dilakukan oleh beberapa orang. Tulisan jurnal juga sudah terbit beberapa kali baik cetak maupun journal online di media internet. Dalam penelitian ini, membutuhkan banyak informasi sebagai pembanding dalam mencapai tujuan penulisan secara akademis.

Penelitian Guritno Himantoro sebagai pembanding lainnya, dimana tesis untuk menyelesaikan studinya di Program Magister Komunikasi Universitas Mercu Buana pada tahun 2009 memakai metode 
penelitian Kualitatif dengan mengangkat masalah "Strategi Grup Media Nusantara Citra Dalam Menyikapi Penerapan Sistem Televisi Berjaringan". Hasil penelitian Guritno Himantoro menampilkan bahwa mengelola bisnis media penyiaran merupakan salah satu bisnis yang paling sulit dan paling menantang dibandingkan dengan jenis industri lainnya. Mengelola media penyiaran pada dasarnya adalah mengelola manusia.

Penelitian selanjutnya dari Afriska Aulia Ilham, tentang "Strategi Manajemen TV Megaswara Bogor dalam Mempertahankan Eksistensinya: Studi Deskriptif Mengenai Strategi Manajemen TV Megaswara Bogor dalam Mempertahankan Eksistensinya dengan Teknik Analisis SWOT". Penelitian yang dibuat oleh Afriska Aulia Ilham bertujuan untuk mengetahui kekuatan, kelemahan, peluang, ancaman dan strategi manajemen TV Megaswara untuk mempertahankan eksistensinya sebagai stasiun TV lokal di Bogor. Metode yang digunakan dalam penelitian ini adalah deskriptif kualitatif dengan analisis SWOT, yang bertujuan untuk menggambarkan serta mengetahui situasi suatu perusahaan. Teknik pengumpulan data diperoleh dengan cara pengamatan, studi pustaka, wawancara mendalam, dan studi dokumentasi.

Penelitian berikutnya adalah dari Anita Wulandari tahun 2004 tentang "Manajemen Televisi Swasta Di Indonesia: Studi Deskriptif Strategi TRANS TV Dalam Meraih Peringkat". Rating adalah segala-galanya bagi bisnis pertelevisian di Indonesia, sehingga dibutuhkan kreatifitas yang tinggi untuk mengelola managen program pada setiap televisi. Perkembangan stasiun televisi di Indonesia semakin marak setelah 10 stasiun TV Swasta dan TVRI melaksanakan siarannya setiap hari. Untuk mempertahankan eksistensinya, maka persaingan gencar antar stasiun TV Swasta pun terjadi. TRANS TV sebagai salah satu stasiun TV Swasta yang relatif masih muda menunjukkan eksistensinya dengan menempati peringkat ke-4 di antara stasiun TV Swasta pada usianya 10 bulan. Penelitian ini dilakukan dengan tujuan mengetahui bagaimana manajemen TRANS TV melaksanakan strategi programming untuk menarik pemirsa yang didukung faktor promosi, teknologi, dan masalah sumber daya manusia. Berkaitan dengan hal tersebut menarik untuk diketahui strategi penjualan slot iklan TRANS TV untuk memperoleh iklan semaksimal mungkin untuk mempertahankan kelangsungan hidupnya sebagai stasiun TV Swasta. Dalam penelitian ini Metodologi yang digunakan dalam penelitian yang dibuat oleh Anita Wulandari adalah pendekatan deskriptif kualitatif melalui in depth interview dengan para narasumber/informan yang diambil dengan teknik snow ball. Dari hasil interview tersebut dan didukung oleh data-data sekunder diperoleh gambaran yang jelas dan terurai mengenai permasalahan dalam penelitian.

Jadi, jika melihat penelitian terdahulu, bahwa penelitian yang dilakukan Sainuddin dan Anita Wulandari mendekati penelitian ini. Sebab menurut analisis peneliti bahwa strategi bagimana memproduksi suatu program televisi pasti bertujuan untuk meningkatkan rating, atau peringkat dalam peraingan stasiun televisi di Indonesia.

Dengan demikian maka yang disuguhkan adalah faktor apa saja yang seharusnya dilakukan oleh pembuat program tersebut, agar programnya bagus dan ditonton orang. Sementara, pada penelitian yang dilakukan Guritno Himantoro, produksi program bukan lagi sekedar untuk membuat program yang baik dan bermutu, tetapi juga pada tataran bagaimana produksi program yang dibuat ketika menghadapi mulai bergulirnya industri televisi ke televisi berjaringan. Jadi menyangkut apa yang harusnya dilakukan produksi program televisi pada industri televisi berjaringan.

Sedangkan hasil dari penelitian Afriska Aulia Ilham menggambarkan bahwa faktor kekuatan dari TV Megaswara antara lain adalah sudah memiliki izin siar dari KPI, brand Megaswara yang menjual dan penonton yang sudah tersegmentasi. Faktor kelemahan dari TV Megaswara antara lain SDM yang terbatas, kualitas dan kuantitas program yang masih rendah, rendahnya minat iklan masyarakat, coverage area yang masih terbatas dan promosi yang masih minim. Faktor peluang dari TV Megaswara antara lain menjual program yang mengedepankan proximity, adanya rasa bangga dan memiliki masyarakat Bogor akan TV lokal dan meningkatkan kerjasama dengan TV lokal lainnya (afiliasi).

Dan faktor ancaman dari TV Megaswara antara lain adalah persaingan dalam perebutan jumlah penonton dan iklan, regulasi dari pemerintah yang mengatakan bahwa di tahun 2012 televisi-televisi lokal akan semakin bermunculan dan kultur masyarakat Bogor yang multi kultur dan jakarta sentris.

Penelitian Afriska Aulia Ilham menggambarkan strategi yang dijalankan departemen program adalah strategi turn-around sedangkan departemen pemasaran adalah strategi diversifikasi. Strategi ini dibuat dengan melihat aspek SWOT pada masing-masing manajemen TV MEGASWARA. Berdasarkan hasil penelitian, saran yang dapat diberikan untuk TV Megaswara adalah supaya TV Megaswara dapat meningkatkan kualitas dan kuantitasnya agar penonton dapat menikmati program acara dengan baik serta 
perbanyak SDM yang berkualitas dan mampu mengemban tanggung jawab untuk memperlancar kerja masing-masing divisi.

Penelitian Anita Wulandari menyatakan bahwa TRANS TV memiliki manajemen yang solid dengan mengandalkan budaya perusahaan yang diidentifikasikan sebagai good corporate governance.

Perubahan yang mendasar dalam strategi programming yang semula mengutamakan acquisition program menjadi in-house production membawa implikasi pada perubahan kebijakan human capital dan strategi keuangan. Strategi penjualan yang 'menjemput bola' juga menghasilkan revenue yang tinggi, sementara overhead cost yang rendah.

Hal ini berpengaruh pada bargaining position yang baik dalam bidang penjualan. Aktivitas promosi dilakukan baik dengan on air dan off air promo, sedangkan pemanfaatan teknologi digunakan serba digital. Selain itu sumber daya manusia yang digunakan TRANS TV adalah $80 \%$ berusia muda di bawah 27 tahun dan $20 \%$ tenaga yang sudah berpengalaman.

Setelah mendapatkan temuan-temuan penelitian, maka dibuatkan ikhtisar, kesimpulan dan implikasi baik dari sisi akademis, yaitu perlunya penelitian lebih lanjut mengenai strategi manajemen komunikasi TV Swasta secara lebih mendalam, juga dengan membandingkan dengan stasiun TV Iainnya. Sedangkan implikasi praktis, penelitian semacam ini menjadi masukan dan pemahaman bagi pengelola media elektronik, khususnya televisi, maupun mitra kerja media televisi.

$\underline{\text { Kerangka Pemikiran }}$

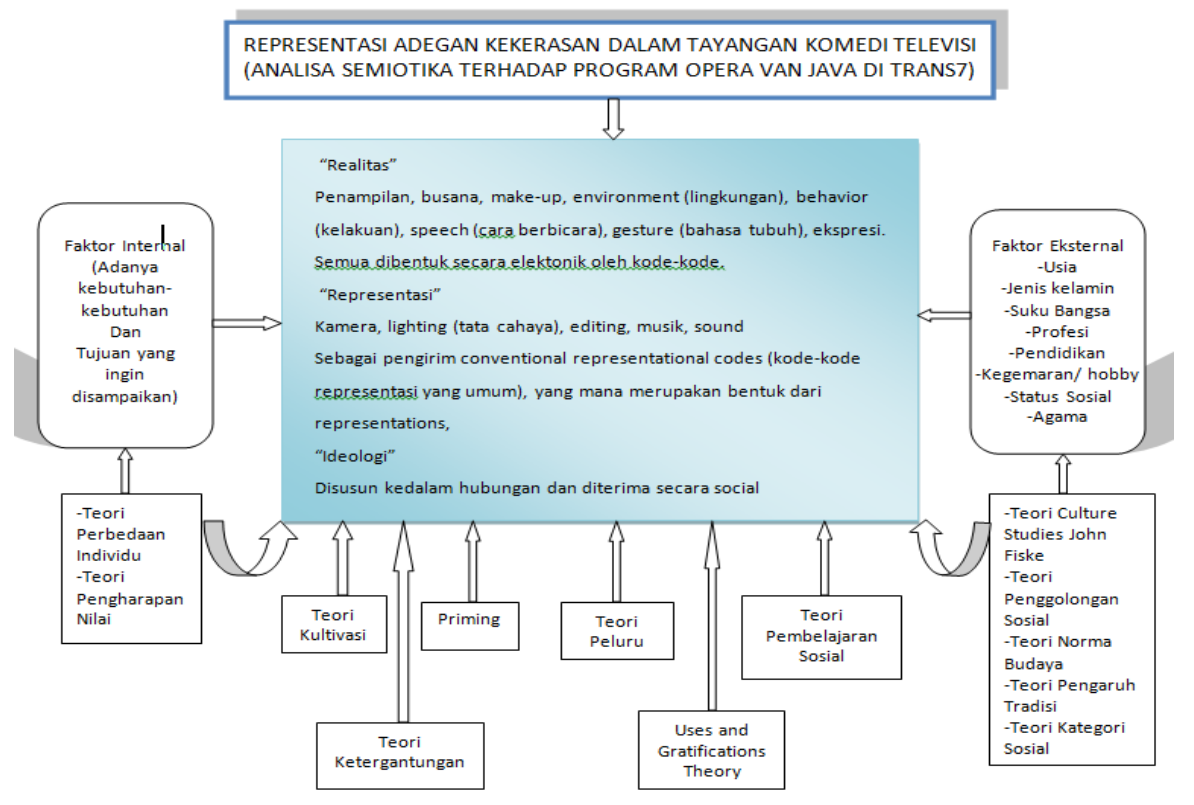

\section{METODOLOGI PENELITIAN}

Objek penelitian ini adalah adegan kekerasan yang terjadi dalam tayangan Opera Van Java (OVJ) baik secara fisik maupun verbal yang dijadikan alat untuk memancing tawa penonton. Pendekatan penelitian yang digunakan dalam penelitian ini adalah pendekatan penelitian Kritis yaitu penelitian yang mengkritisi dengan meruntuhkan mitos dan memberdayakan orang guna merubah masyarakat secara radikal, serta konflik dibuat dan diatur dengan struktur yang tersembunyi karena sifat manusia yang kreatif dan adaptif namun dijebak oleh ilusi dan eksploitasi (Neuman at all, tahunnn).

Metode yang digunakan dalam penelitian ini adalah metode penelitian kualitatif deskriptif. Moleong (1984: 16) mengemukakan bahwa metode penelitian kualitatif merupakan prosedur penelitian yang mengahasilkan data deskriptif berupa kata-kata tertulis atau lisan tentang sifat suatu individu, keadaan, atau gejala dari kelompok tertentu yang diamati.

Pendekatan penelitian ini adalah pendekatan kualitatif dengan analisis semiotika/ tanda yakni

-Suatu yang atas dasar konvensi sosial yang terbangun sebelumnya, dapat dianggap mewakili sesuatu yang lain.

-Ilmu yang mempelajari tentang sederetan luas objek-objek, peristiwa-peristiwa, seluruh kebudayaan sebagai tanda. 
-Menurut Little John, manusia dengan perantaraan tanda-tanda dapat melakukan komunikasi dengan sesamanya dan banyak hal yang bisa dikomunikasikan di dunia ini. Metodologi yang digunakan dalam analisis semiotika adalah interpretatif. Secara metodologis, kritisme yang terkandung dalam teori-teori interpretatif -utamanya hermeneutika- menyebabkan cara berpikir mazhab kritis (Frankfrut School) terbawa juga dalam kajian semiotik ini. Sesuai dengan paradigma kritis, analisis semiotik bersifat kualitatif. Jenis penelitian ini memberi peluang yang besar bagi dibuatnya interprestasi-interprestasi alternatif.

Ada tiga jenis masalah yang hendak diulas dalam analisis / metode semiotika. Pertama, masalah makna. Bagaimana orang memahami pesan? Informasi apa yang dikandung dalam stuktur sebuah pesan? Kedua, masalah tindakan atau pengetahuan tentang bagaimana memperoleh sesuatu melalui pembicaraan. Ketiga, masalah koherensi, yang menggambarkan bagaimana membentuk suatu pola pembicaraan masuk akal dan dapat dimengerti.

Teknik pengumpulan data dalam penelitian ini adalah:

- Data Primer, yang didapat melalui teks yang terdapat dalam tayangan komedi program Opera Van Java (OVJ) di Trans7.

- Data Sekunder, yang didapat dari studi pustaka yang meliputi segala informasi menyangkut tentang adegan kekerasan dalam tayanga komedi Opera Van Java (OVJ).

\section{HASIL DAN PEMBAHASAN}

Hasil

Bisnis media yang sedang bertumbuh seperti perusahaan PT Duta Visual Nusantara Tivi Tujuh yang mengoperasionalkan stasiun televisi Trans7, tujuan yang hendak dicapai adalah memberikan keuntungan bagi stake holder atau pemilik modal. Untuk itu, maka semua strategi, kebijakan dan langkah yang diambil oleh para direksi, manajer dan karyawan adalah untuk sebesar-besarnya kepentingan perusahaan dalam rangka memperoleh laba sebesar-sebesarnya. Seperti dikatakan oleh Wishnutama Kusbandio (wawancara 22 Juli 2013), yang menjadi Direktur Utama pertama perusahaan setelah diambil alih oleh Trans Corp, sebagai berikut;

"Semua lini di perusahaan ini harus mengetahui, bahwa tujuan perusahaan adalah memberikan keuntungan bagi perusahaan, dan ini harus ada dalam pemikiran mereka, bahkan harus ada dalam setiap langkah mereka".

Direktur Utama kedua Atiek Nur Wahyuni menjelaskan bahwa (wawancara 29 Juli 2013), saat ini juga menyebutkan,

"Kita harus punya jiwa untuk memberikan yang terbaik untuk perusahaan ini. Kalau perlu di tiap tarikan nafas mereka adalah untuk keuntungan perusahaan".

Hasil penelitian ini terdiri dari bagaimana upaya peningkatan rating dan share program OVJ di Trans7.

Penyajian data terdiri dari hasil wawancara dan gambaran grafik survey dari AGB Nielsen yaitu : Dalam penelitian ini, dilakukan pendalaman penelitian untuk melihat sejauh mana komunikasi kreatif yang dilakukan oleh manajemen OVJ (Opera Van Java) itu berhasil menaikkan peringkat penontonnya. Adapun yang diwawancarai adalah :

1. Pakar Televisi

2. Manajemen pelaksana program Opera Van Java

3. Pihak Penonton yang disebut pemirsa

4. Manajemen Trans7

Wawancara dilakukan untuk mendalami pendapat para informan sesuai dengan fokus penelitian. Berdasarkan hasil wawancara dapat diverifikasi bahwa

1). Pembahasan Wawancara Pakar Televisi; Script interview di bawah ini dapat dijelaskan pada tabel adalah Wawancara Dengan Pakar Televisi Ade Armando; Seorang pakar komunikasi Pertelevisian di Indonesia dari Universitas Indonesia yang sudah diakui oleh media dan juga dikalangan bisnis broadcasting Indonesia. Banyak menulis artikel tentang startegi televisi atau broacasting di Indonesia. Peneliti telah mewawancarai beliau dari sisi pandangan umum mengenai perkembangan televisi dan persaingannya.

Dalam menganalisa hasil wawancara kepada nara sumber tentang pertanyaan Bagaimana menurut bapak acara-acara komedi di stasiun televisi pada umunya? Menjawab bahwa OVJ Sangat Kreatif, sekalipun Acara Televisi Indonesia ke depan lebih banyak menayangkan tentang pemilu dari pada program komedi. Acara yang di dominasi oleh program Kampanye itu berhubung karena tahun ini adalah tahun politik. Bukan berarti acara lain akan ketinggalan. OVJ saya rasa tetap laku keras, kreatifitas mereka masih bisa mencuri 
perhatian penonton. Hal ini menunjukkan bahwa pemirsa sudah bisa menilai bahwa acara mana yang bisa dan layak ditonton karena alasan kreatifitas dan mana yang tidak.

4. Pihak Manajemen Trans7; Pihak manajemen yang diwawancara terdiri atas :

(1) Wishnutama Kusbandio, Direktur Utama Trans7 (2006-2008) dan Direktur Produksi Trans7 (20062012).

(2) Atiek Nur Wahyuni, Direktur Utama Trans7 (2008-sekarang) dan Direktur Programming dan Sales Marketing Trans7 (2006-sekarang).

(3) Ahmad Ferizqo Irwan, Kepala Divisi Programming (2006-sekarang).

Beberapa komentar dari para pihak manajemen narasumber memberikan komentar tentang bagaimana mengurus manajemen stasiun televisi Trans7. Orang-orang ini adalah yang bertanggungjawab terhadap secara langsung terhadap berbagai kebijakan manajemen termasuk mengawasi keberadaan program "Opera Van Java" (OVJ), baik dari sisi produksi maupun penayangan program.

\section{Performance Rating dan Share Program Komedi OVJ Trans7}

Menurut AGB Nielsen, bahwa program Komedi Opera Van Java (OVJ) merupakan tayangan komedi yang berhasil membuat sebagian besar penontonnya menjadi setia menonton tayangan ini. Menurut rating AGB Nielsen Rabu, OVJ mengumpulkan TVR 6,9 dan share 26,2. Format OVJ seperti pementasan wayang orang yang lengkap dengan dalang, sinden dan para pemain gamelan. Cerita-cerita yang dibawakan tidak hanya seputar legenda maupun cerita rakyat lokal, tapi juga berasal dari cerita film, gosip selebriti sampai fiksi yang memang dibuat dengan tema kehidupan sehari-hari. Segala hal konyol dilakukan oleh para pemainnya untuk membuat penonton tertawa. Satu hal yang menjadi ciri khas lawakannya adalah penggunaan properti Styrofoam. Properti ini menjadi andalan mereka untuk menciptakan tawa dari penontonnya. Bisa dengan cara mendorong salah satu pemain hingga dia terjatuh menimpa properti, memukulkan properti tersebut pada pemain lainnya, dan masih banyak lagi. Tak hanya itu, cara mereka membuat lawakan pun tidak lepas dari ejekan para pemainnya. Adegan - adegan seperti inilah yang menjadi sorotan dalam model perencanaan pemecahan masalah kekerasan dalam tayangan komedi Opera Van Java (OVJ) di Trans7. Ide cerita yang berbeda dengan tayangan komedi sebelum-sebelumnya menciptakan hal baru yang digemari pemirsanya. Dengan tampilan wayang orang, OVJ mampu membuat para penontonnya puas tertawa oleh tingkah polah para pemainnya. Menjadi favorit pemirsanya, OVJ membuktikan kejayaannya di Panasonic Gobel Awards ke 13 kemarin dengan berhasil meraih satu penghargaan sebagai program komedi terfavorit.

Survey AGB Nielsen pada Acara OVJ Trans7, data yang didapatkan dari AGB Nielsen menunjukkan bahwa selama enam bulan berturut-turut acara OVJ menduduki peringkat tertinggi dibandingkan acara komedi lainnya. Data yang diambil dimulai sejak pebruari 2013 sampai pada bulan Juli 2013. Selama 6 bulan berturut-turut rating dan share OVJ sangat memuaskan, namun peneliti tidak menampilkan data televisi lainnya karena tidak mendapat izin dari sumber data. Berikut adalah data grafik tersebut:

a) Performance OVJ pada Periode Februari 2013

Pada grafik dibawah ini AGB Nielsen memperlihatkan bahwa minggu pertama sampai minggu ke empat pada bulan Februari 2013 OVJ di TV rating berada pada 3,7 dan tertinggi 4,2 sedangkan Share terendah pada poin 14.6 dan tertinggi pada 16.9 .

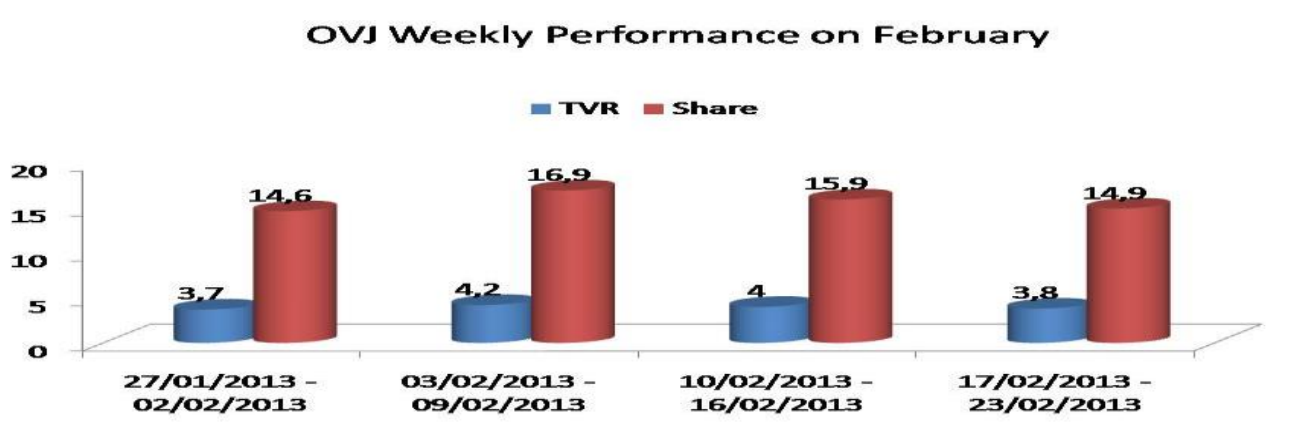


b) Performance OVJ pada Periode Maret 2013; Pada grafik dibawah ini AGB Nielsen memperlihatkan bahwa minggu pertama sampai minggu ke empat pada bulan Maret 2013 OVJ di TV rating berada pada 3,4 dan tertinggi 4,3 sedangkan share terendah pada poin 13.5 dan tertinggi pada 16.8.

OVJ Weekly Performance on March

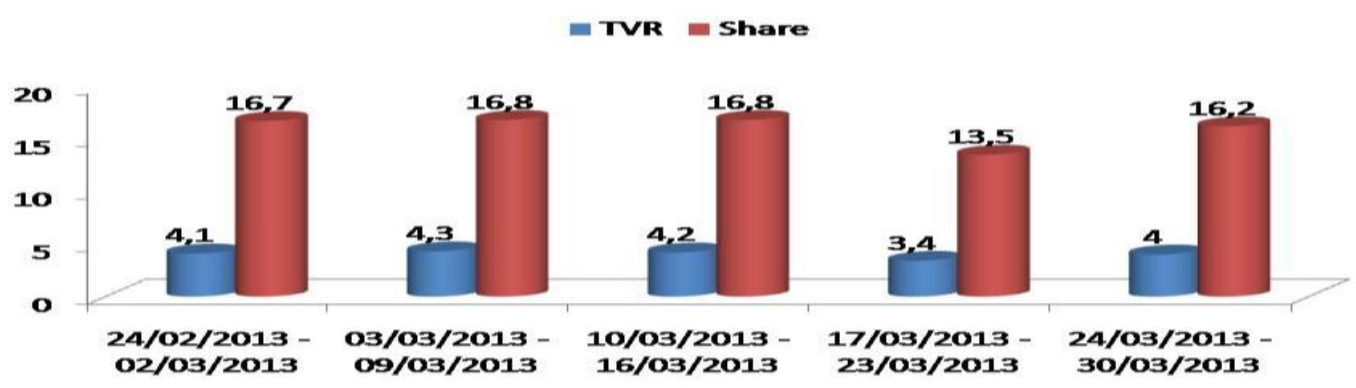

Performance OVJ pada Periode April 2013 Pada grafik dibawah ini AGB Nielsen memperlihatkan bahwa minggu pertama sampai minggu ke empat bahwa OVJ di TV rating berada pada 3,7 dan tertinggi 4,2 sedangkan share terendah pada poin 14.6 dan tertinggi pada 17.2.

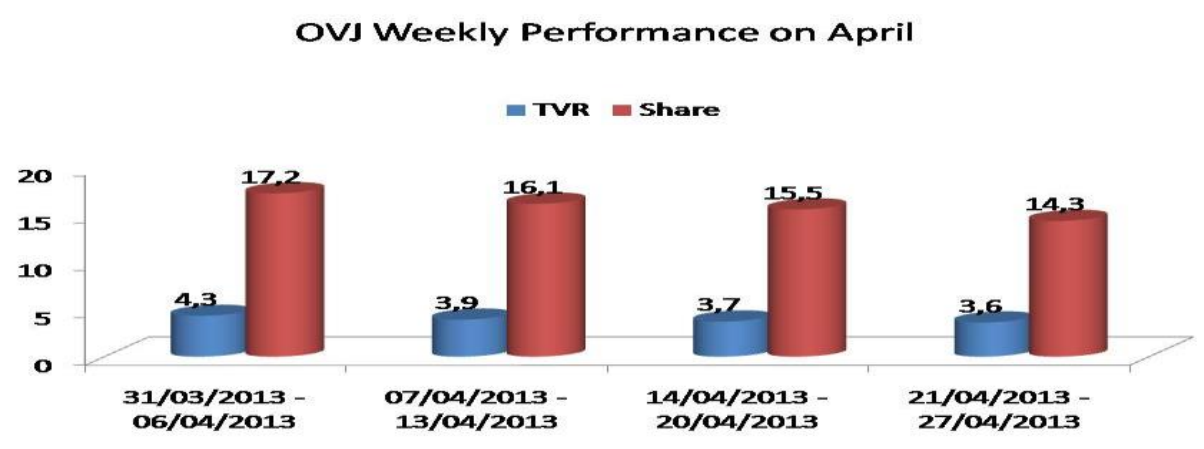

Performance OVJ pada Periode Mei 2013 Pada grafik dibawah ini AGB Nielsen memperlihatkan bahwa minggu pertama sampai minggu ke empat bahwa OVJ di TV rating berada pada 3,7 dan tertinggi 4,2 sedangkan share terendah pada poin 14.6 dan tertinggi pada 16.0.

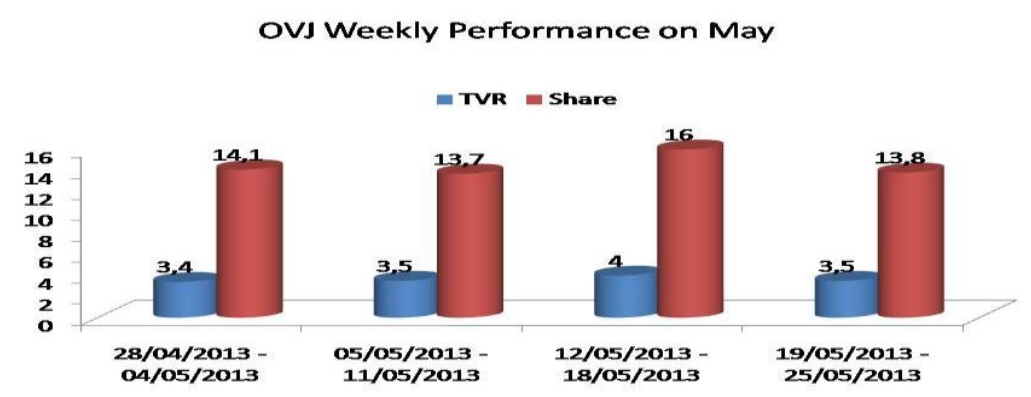

c) Performance OVJ pada Periode Juni 2013 Pada grafik dibawah ini AGB Nielsen memperlihatkan bahwa minggu pertama sampai minggu ke empat pada bulan Juni 2013 OVJ di TV rating berada pada 3,7 dan tertinggi 4,2 sedangkan share terendah pada poin 14.6 dan tertinggi pada 15.1. 


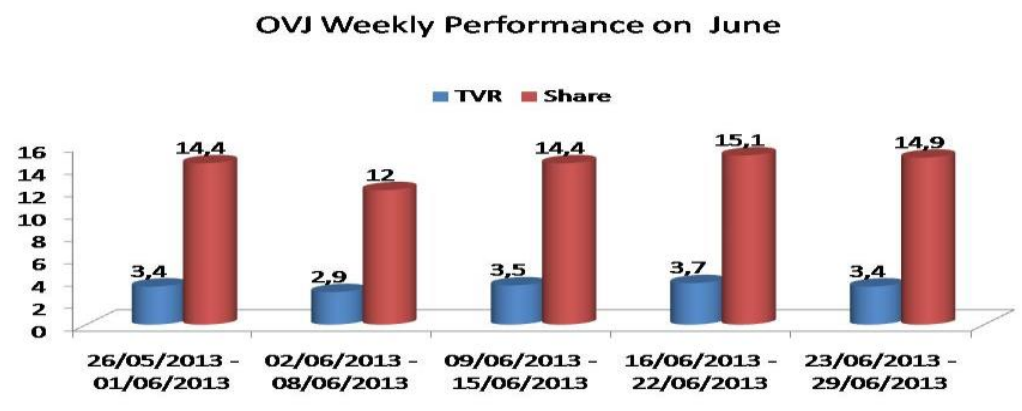

d) Performance OVJ pada Periode Juli 2013 Pada grafik dibawah ini AGB Nielsen memperlihatkan bahwa minggu pertama sampai minggu ke empat bahwa OVJ di TV rating berada pada 3,7 dan tertinggi 4,2 sedangkan share terendah pada poin 14.6 dan tertinggi pada 16.8 .

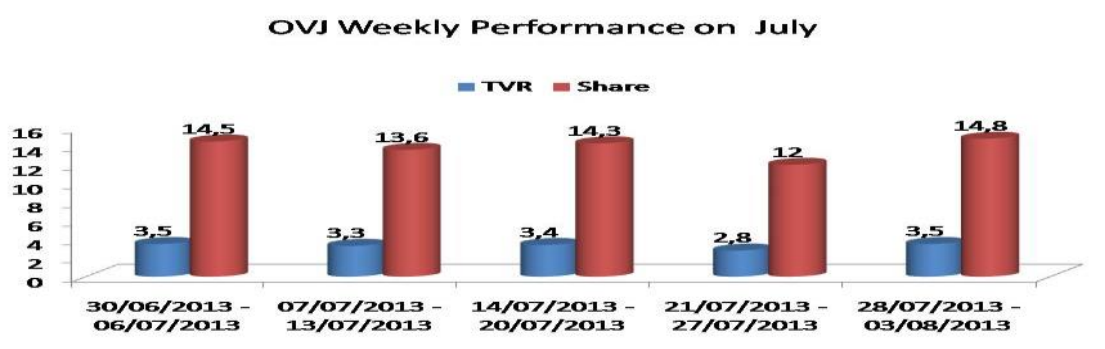

\section{Pembahasan}

Upaya Peningkatan Rating dan Share Trans7

Upaya peningkatan rating and share agar mendapatkan penonton sebanyak-banyaknya dan menahan penonton selama-lamanya, menjadi beban sehari-hari yang harus ditanggung manajemen dari para pembuat program dari Divisi News dan Produksi. Kadang kala, usaha ini sukses dengan keberhasilan membuat kreatifitas program yang disenangi penonton dan mendapatkan pemasang iklan yang cukup banyak. Namun, juga terkadang upaya tersebut menemui kegagalan, programnya berantakan sehingga ditinggalkan penonton dan pemasang iklan. Menghadapi tekanan seperti inilah yang seringkali membuat manajemen dan kreator pembuat program dari Divisi Produksi dan News kehilangan kesabaran dan menayangkan program asalasalan.

Filosofi bisnis yang dilakukan Trans7 adalah setiap karyawan untuk selalu fokus dan setiap saat hanya memikirkan bagaimana membuat Trans7 maju dan menadatngkan keuntungan bagi perusahaan ini. Berdasarkan pengamatan langsung peneliti, memang terlihat bagaimana pimpinan perusahaan untuk mendisiplinkan karyawannya untuk tetap fokus pada kepentingan perusahaan. Salah satu contoh yang memperlihatkan hal tersebut adalah ketat dan disiplinnya mereka dalam pengajuan dan penggunaan budget program.

Bisnis media khususnya televisi memiliki biaya operasional yang tinggi, ini salah satu kelemahan televisi sebagai suatu industri, yaitu mahalnya biaya operasional dalam melakukan siaran televisi, termasuk diantaranya adalah mahalnya biaya penadaan program. Dengan membuat program sendiri dan mengontrol anggarannya secara ketat, maka salah satu kendala televisi selalu berbiaya mahal dalam produksi programnya, bisa sedikit ditekan. Jika hal tersebut secara konsisten mereka terapkan, maka margin keuntungan yang akan diterima perusahaan akan semakin membesar, seiring dengan ditekannya pengeluaran perusahaan (Baksin, 2009; 24-29).

Pengalaman orang yang pernah dan masih menjabat sebagai Direktur Utama di Trans7 yang juga sempat mengelola TV7, sebelum masuknya manajemen Trans Corp. Menyatakan selama lima tahun lebih perusahaan tersebut beroperasional, tidak pernah membukukan keuntungan. Hasilnya, pemilik modal dalam hal ini Kelompok Kompas Gramedia (KKG) selalu harus menambah modal atau menutup biaya operasional untuk kelangsungan perusahaan. Pernyataan Wishnutama Kusbandio (wawancara 22 Juli 2013) berikut bisa mewakili sikap seperti di bawah ini, 
"Trans7 tidak boleh mengalami hal yang sama dengan TV7 lalu, karena pemilik modal sekarang sudah menyatakan dengan tegas bahwa tidak ada tambahan modal lagi untuk Trans7, setelah dibeli oleh Trans Corp".

Dari pengamatan yang dilakukan, bila ditinjau dari perkembangan bisnis yang dijalankan Trans7 saat ini, bisnis sudah dijalankan sebagaimana mestinya. Hal itu berbeda jauh dengan ketika masih menggunakan nama TV7 yang pengelolaannya kurang bagus, sehingga membuat perusahaan ini terus menderita kerugian setiap tahunnya. Melalui pengamatan secara langsung, memang orientasi bisnis yang dijalankannya sangat disiplin dan berdasarkan semata keuntungan perusahaan. Proyek-proyek pembelian program yang harganya mahal yang belum tentu bisa dijual atau sulit tertutup biaya pembelian programnya, dikaji ulang. Salah satu contoh konkretnya adalah saat tidak lagi memperpanjang hak siarnya Liga Inggris pada musim 2007-2008. Meski program tersebut punya awareness dan gengsi yang tinggi, namun besarnya harga hak siarnya, ditambah sulitnya menutupi biaya pembelian program tersebut, menyebabkan manajemen Trans7 lebih memilih untuk tidak lagi membeli hak siar pertandingan Liga Inggris tersebut.

Secara sederhana, bisnis televisi adalah bagaimana caranya mendapatkan uang sebesar-besarnya dari penjualan iklan, serta bagaimana caranya menekan biaya pengadaan program serendah-rendahnya dan bagaimana caranya mengurangi biaya operasional sebanyak-banyaknya. Menurut Wishnutama Kusbandio (wawancara 22 Juli 2013), strategi itu dengan jelas diterapkan di Trans7 setelah diambil alih manajemen Trans Corp adalah sebagai berikut;

"Untuk mendapatkan uang sebesar-besarnya mereka berupaya untuk memperbanyak iklan masuk dan menaikkan harga iklan tersebut. Sementara untuk menekan biaya program, Trans7 sama seperti Trans TV memperbanyak program-program in house production yang jelas jauh lebih murah. Terakhir, untuk menekan biaya operasional, Trans7 menerapkan banyak penghematan dalam berbagai kegiatan usaha mereka"

Kesimpulannya untuk bertahan dan memenangkan persaingan di industri ini sebenarnya rumusnya sangat sederhana. Syaratnya adalah memiliki program yang banyak ditonton yaitu dengan rating dan share yang tinggi, sehingga mengundang pemasang iklan. Selain itu perlu meminimalkan biaya-biaya yang tidak perlu, sehingga akan mengurangi beban biaya operasional.

\section{Manajemen Komunikasi Yang Kreatif Untuk Peningkatan Rating Program OVJ Trans7}

Opera Van Java (OVJ) adalah salah satu pilihan favorit para penonton program komedi televisi. Tentu saja, untuk bertahan sampai sejauh ini, tim OVJ harus dihuni oleh mereka yang memiliki kreatifitas tinggi. Hal ini menjadi penting untuk mencegah kebosanan penonton yang diakibatkan oleh alur dan setting cerita yang monoton. Untuk masalah kreatifitas, saya pikir OVJ memang juaranya. Para wayang OVJ pun memiliki tingkat improvisasi yang tinggi, sehingga jalan cerita kadang menjadi kacau yang justru dengan kekacauan ini, kelucuan pun terjadi. Saya pun ikut menikmati dan terpingkal-pingkal.

Mungkin para penyuka OVJ sudah sangat paham dengan adegan "mengagetkan" lawan main di OVJ. Sosok Azis dan bintang tamu, seperti Bopak, seringkali menjadi sasaran kejahilan Andre, Sule, Parto, Nunung dan tim kreatif. Sepert dalam salah satu episode, Bopak harus menerima kenyataan karena terus saja dikagetkan dengan sebuah tiruan pocong yang tiba-tiba jatuh dari langit-langit ruangan. Spontan saja, Bopak harus berlari sekencang mungkin meninggalkan pentas karena kaget. Saat adegan itu berlangsung, Azis pun kaget dan berlari keluar. Penonton pun menjerit karena kaget akibat adegan yang tiba-tiba tersebut dan begitu mengagetkan. Namun, adegan tersebut tetap saja membuat suasana menjadi lucu karena aksi Bopak yang terkaget-kaget. Dan siapa yang tak kenal dengan kata-kata "YAA'EEEE......".Pasti semua orang mengenal kata-kata tersebut. Ya...kata-kata tersebut merupakan ciri khas dari acara Opera Van Java, yang hadir dari senin sampai sabtu malam. Acara Opera Van Java (OVJ) merupakan sebuah acara komedi yang hadir di stasiun TV Trans 7.

Dengan beberapa pemain yang dimilki OVJ membuat acara ini diminati hampir di semua lapisan masyarakat. Dipimpin oleh Parto Patrio yang bertindak sebagai Dalang dan diikuti oleh wayang-wayang lainnya seperti Sule, Azis Gagap, Andre Taulani, Nunung dan 2 Sinden Cantik yang selalu ada menemani dalang. Dengan memilki karakter yang beragam di tiap pemain (wayang) menjadikan Rating acara ini menjadi yang tertinggi dibanding dengan acara lain. Namun di balik kesuksesan itu sangat berperan penting sekali yaitu tim kreatif OVJ. Yang dimana acara ini memiliki property yang boleh di bilang aneh-aneh, seperti misalnya adanya tangan orang, semprotan nyamuk, mobil, motor, gerobak, telepon, hp, bajaj dan lain sebagainya yang terbuat dari bahan sterofoam.

Sebutan untuk para penggemar OVJ sendiri yaitu OVJ Mania. Kegilaan yang ditimbulkan oleh para pemain (wayang) membuat para penonton tertawa terpingkal-pingkal. Seperti misalnya saat masuk ke cerita 
tiba-tiba Azis Gagap datang memakai peci layaknya ustadz yang ingin memberikan ceramah. Nah keanehan dan kelucuan itu lah yang membuat acara ini sangat diminati oleh penonton televise yang membutuhkan hiburan untuk menghilangkan penat dan stress setelah seharian penuh sibuk beraktivitas, Selain itu di tiap pemain memiliki kata-kata sendiri seperti Parto ketika para pemain sudah memasuki cerita namun melenceng dari cerita tersebut sang dalang berkata "Eh pada ngapain itu ayo masuk Benang merah" lalu para pemain mengatakan " OKE lah Kalau Begitu "Banyak lagi hal lainnya hingga tidak bisa menyebutkan satu per satu kegilaan para pemain dalam memainkan perannya. Namun begitu acara ini juga membawa dampak yang positif bagi masyarakat karena acara OVJ karena bisa memberikan terobosan baru di dunia perlawakan.

Hal ini berarti, bahwa komedian yang kreatif adalah ia yang mampu merangkai berbagai asos 1iasi, dan mempertentangkannya hingga ke tingkat ekstrem sedemikian. Meskipun belum maksimal, apa yang dilakukan Parto,Nunung, Azis,Sule dan Andre sebagai pemain tetap OVJ dengan arahan tim kreatif, assistan produser dan produser OVJ sangat menghibur penonton program OVJ.

Strategi umum Trans7 dalam mengembangkan bisnis usahanya adalah dengan menekan biaya program, demi mendapatkan keuntungan yang jauh lebih besar. Artinya, strategi bisnis yang dijalankan adalah dengan memperbanyak program yang dibuat sendiri (in house production) untuk mengisi jam siarannya. Jika dibanding dengan membeli program yang sudah jadi, baik dari rumah-rumah produksi di dalam negeri maupun membeli program, film atau even-even pertandingan olahraga dari distributor di luar negeri, yang harganya jauh lebih mahal, maka membuat program sendiri, jelas jauh lebih kecil biayanya. Upaya menekan biaya untuk mengadaan program inilah yang membuat Trans7 lebih banyak mendapatkan keuntungan, karena rendahnya biaya program dibanding stasiun televisi yang jam siarannya lebih banyak diisi dengan membeli program dari luar.

Manajemen komunikasi televisi stasiun Trans7 dalam mengelola program komedi, membangun sinergi/kinerja semua kru untuk mengkomunikasikan ide-ide kreatif dan gagasan, menyamakan persepsi, mengemas pesan dan kesan sehingga menciptakan produk yaitu program OVJ yang menarik untuk penonton dan pesannya sampai ke penonton semua kalangan dan semua umur, sehingga OVJ tetap menduduki posisi pertama dalam rating acara sejenisnya kategori komedian.

Sangat fenomenal, ketika data menunjukkan bahwa OVJ meraih perhatian penonton pada tingkat tertinggi (rating tertinggi) dibandingkan dengan acara pada kategori komedian yang sama. Makin Jail dan Iseng Banget merupakan jenis komedi yang melibatkan publik. Makin Jail, publik dijadikan objek yang diganggu hingga menimbulkan rasa takut, marah, geli, dan seterusnya. Karena diganggu sedemikian, publik tidak berada dalam suasana senang, sampai kemudian mereka diberitahu bahwa "si jail" hanyalah utusan televisi. Mereka pun tertawa. Sedangkan di luar layar, isi perut penonton dikoyak justru ketika publik di dalam televisi tengah menjadi korban. Dengan kata lain, penonton diajak menertawakan penderitaan orang lain, dan strategi ini kalah oleh kreatif OVJ.

Kemampuan OVJ mendapat mendapat rating tertinggi pada program komedi Televisi yang menarik perhatian penonton dibanding acara lainnya pada kategori komedi yang menjamur di TV local adalah Berbanding lurus dengan Makin Jail adalah Iseng Banget. Bedanya, jika pada Makin Jail yang menetralisir suasana adalah kamera, pada Iseng Banget adalah komedian Komeng, yang muncul ketika gangguan terhadap publik berada pada klimaks. Publik yang telah mengetahui sosok Komeng sebagai komedian popular, dengan sendirinya merasa maklum bahwa mereka sedang berada "di dalam televisi". Agak sulit bagi kita untuk menemukan substansi komedi yang diolah di dalamnya, karena mereka hanya mengganggu publik. Jika untuk mengidentifikasi materi kelucuannya sendiri susah, bagaimana, misalnya, kita bisa menemukan sedikit saja nilai pendidikan, kritik, renungan, dan lain-lain? Tayangan ini hanya memproduksi tawa pada lapis paling luar dan dangkal; sebuah kamuflase komedi. Tawa yang diproduksi seolah-olah untuk publik itu, justru lebih banyak diperuntukkan bagi kepentingan industri televisi sendiri.

Tampak pada adegan tersebut bahwa sumber tawa ada di ujung kamera. Artinya, komedi ini tidak mengidentifikasi para pemainnya sebagai komedian, sebab "siapa pun" bisa melakukan hal tersebut. Walhasil, kecuali memainkan kamera, kita tidak menemukan kreativitas pada tayangan tersebut. Pesan-pesan dalam setiap lawakan OVJ dapat diterima dengan baik, sekalipun ringan dan menyindir kehidupan sosial masyarakat yang cenderung melanggar aturan dan etika, menjadi ingat kembali nasihat yang tersirat dalam acara lawakan itu.

Kemampuan personil komedian Sule, Andre, Parto, Azis dan Nunung, sebenarnya memungkinkan munculnya sebuah komedi yang bagus: lucu sekaligus mengandung hal-hal berfaedah di dalamnya. Utile et dulce, bermanfaat dan nikmat, demikian mengutip Horatius. Akan tetapi, tentu saja semuanya kembali pada pemilik dan pengelola televisi: sebatas mana mereka memiliki keberpihakan pada kepentingan publik; dalam 
hal ini ikut mencerdaskan publik, sekecil apa pun. Di sisi lain, para komedian berbakat juga agaknya tidak memiliki daya di hadapan industri. Mereka pekerja industri itu sendiri. Mereka eksis menjadi subjek komedian, tapi sekaligus menjadi objek industri.

Padahal, komedi sebagai bagian dari sarana retorika memiliki peluang besar untuk membalikkan berbagai mitos identitas hegemonik. Penonton dapat dipersuasi tanpa sadar karena unsur gembira yang diproduksi komedi. Itu sebabnya pula, dalam teori kreativitas, humor (di dalamnya tentu saja komedi), merupakan interaksi komunikasi yang sarat dengan unsur kreativitas. Di dalam humor, berbagai asosiasi (bisosiasi) dipertentangkan sampai pada batas maksimal, sehingga menimbulkan ketegangan yang tidak memiliki penyelesaian kecuali dengan tertawa (Arthur Koestler, dalam Heraty, 1983). Kreativitas

minimal yang berperan sangat besar, secara umum, ketimbang mencerminkan unsur kreatif dalam pengertian Koestler di atas, komedi televisi kita justru malah banyak membekukan asosiasi, bahkan mematikan daya kretavitas itu sendiri.

\section{Analisis Unit Proses Produksi Program OVJ Trans7}

Strategi yang mengandalkan in house production, tentu membawa konsekuensi tersendiri bagi manajemen Trans7. Salah satu konsekuensinya adalah harus adanya dukungan yang kuat dari Divisi News dan Divisi Produksi yang membuat program-program tersebut. Dukungan tersebut adalah dengan tersedianya sumber daya manusia yang memadai, baik dari segi kuantitas maupun kualitas, untuk bisa memproduksi program yang mampu bersaing dengan program-program yang ditayangkan stasiun televisi lainnya. Upaya untuk meningkatkan kreatifitas dan kualitas bagi sumber daya manusia yang membuat program-program di Trans7, menjadi pekerjaan rumah utama manajemen Trans7, yang selalu menjadi fokus utama mereka.

Persiapan SDM (sumber daya Manusia) disiapkan dengan memberikan berbagai training atau pelatihan, reward dan funishment selalu ditujukan agar para kreator pembuat program di Divisi Produksi dan Divisi News menghasilkan dan membuat program yang punya rating dan share yang tinggi. Keberhasilan membuat program yang rating dan sharenya tinggi, akan memudahkan stasiun televisi ini menarik para pemasang iklan. Tidak heran, jika target rating dan share yang tinggi, berdasarkan data yang dikeluarkan oleh AGB Nielsen tiap harinya, menjadi suatu kewajiban. Bahkan, ada penilaian yang baik, bagi team produksi yang sukses membuat program yang punya rating dan share tinggi. Tidak itu saja, manajemen Trans7 juga mengiming-imingi bonus uang dalam jumlah tertentu bagi team produksi yang programnya berhasil menembus target rating dan share yang sudah ditentukan. Sebaliknya, bagi para kreator pembuat program yang gagal, akan mendapatkan penilaian yang buruk dan programnya akan dihentikan penayangannya, jika dalam waktu tertentu menurun terus performence rating dan sharenya.

Selalu saja ada kendala jika dilihat dimasa lalu, upaya untuk membuat program yang disenangi penonton dan pemasang iklan terkadang kerap menabrak aturan main atau rambu-rambu dalam regulasi penyiaran yang berlaku, tidak banyak upaya yang dilakukan manajemen Trans7 untuk mengajak para kreator programnya, baik dari Divisi Produksi maupun Divisi News serta para peramu penyusunan program acara dari Divisi Programming untuk mengetahui, mengenal, memahami dan mengutamakan program seperti OVJ untuk mendobrak rating (peringkat).

Sikap manajemen Trans7 untuk lebih fokus pada upaya untuk membuat program-program yang sukses secara rating, share dan penjualan iklannya. Penerimaan dari iklan adalah bagian mata rantai dari acara yang baik, pertumbuhan Trans7 telah membuktikannya, sekalipun masih ada kekurangan pada bagian frame time tertentu.

Proses kontrol internal selalu menjadi perhatian khusus pada bisnis televisi. Program-program yang akan tayang, biasanya hanya melalui kontrol internal per departemen (bagian), sehingga kadang-kadang masih sering kecerobohan karena ada adegan ataupun isi program yang ternyata melanggar aturan main atau regulasi penyiaran. Sudah banyak kasus yang mengakibat acara dihentikan karena salah mengontrol setiap program, kadang diakibatkan karena kejar tayang yaitu waktu yang mendesak. Tanggungjawab itu memang akhirnya diberikan kepada bagian Quality Control (QC) di bawah Divisi Programming, yang menjadi supervisor tayangan atau program, bukan saja secara teknis, kualitas video ataupun audionya, tetapi juga isi atau content program.

Jika sebuah program dilihat materinya oleh QC, dan ternyata ditemukan adanya pelanggaran tergadap regulasi penyiaran, maka program tersebut tidak diperkenankan untuk ditayangkan, dan dikembalikan ke pembuatnya, dari Divisi Produksi atau News untuk direvisi. Sayangnya kebijakan memperluas kerja dan wewenang QC untuk mensupervisi isi program ini, manajemen Trans7 sangat jeli dalam memilih program acara yang sangat baik. Selain itu kerjasama tim (team work) seluruh kru produksi 
OVJ sangat dibutuhkan, seperti antara bagian wardrobe, make up artist, property, set up panggung, talent, Unit Production Manager (UPM), Creative, Floor Dircetor (FD), Production Director (PD), Produser, Executive Producer (EP) sampai Production Manager menjadi satu kesatuan yang saling membutuhkan satu sama lain untuk menghasilkan program OVJ yang menarik sehingga menaikkan rating \& share.

\section{Strategi Unit Produksi Program OVJ Trans7}

Team Produksi Program OVJ Trans7, sudah berpengalaman memproduksi banyak acara, tanpa mengabaikan unsur budaya dan sosial masyarakat, termasuk mengantisipasi regulasi penyiaran dan KPI sehingga tidak menjadi penghalang atau tidak menjadi hal yang menakutkan. Team ini bertugas untuk menaikan kualitas program, tanpa mengabaikan aturan yang berlaku. Hal ini bukan penghalang bagi Divisi Produksi untuk menghasilkan produk yang baik, regulasi adalah baik dan bukan bermaksud mematikan kreatifitas dari seorang team divisi produksi.

Performance program yang sedang mengalami penurunan, bukan disebabkan oleh karena regulasi, tetapi kreatifitas yang sudah mulai berkurang, maka terkadang produser dan produser eksekutif jangan mencari alasan mengapa rating itu turun. Tuntutan untuk bisa mengembalikan performence yang turun, memang menjadi fokus yang harus diperhatikan setiap anggota team. Apalagi, ada evaluasi keberlangsungan program yang tiga minggu berturut-turut mengalami penurunan. Jika tidak ada perbaikan, bukan tidak mungkin program tersebut akan dihentikan penayangannya, dan itu berarti catatan buruk bagi team yang pernah mengerjakannya. Seperti yang diutarakan oleh Ahmad Ferizqo Irwan (wawancara 8 Juli 2013) berikut ini,

"Kita memang selalu melakukan evaluasi terhadap performance program. Program itu nggak boleh tiga minggu terus turun. Kalau nggak diperbaiki, pasti bisa diberentiin programnya. Kalau sampai ditutup, nilai yang buat itu program juga ikutan jelek".

Dalam pengamatan peneliti, performence program, yang dinilai dari pencapaian share dan rating tertinggi untuk program-program Produksi, memang menjadi sesuatu yang tidak bisa ditawar, karena itulah yang nantinya digunakan untuk menjaring iklan. Jadi, jika ada program yang mengalami penurunan tiga minggu berturut-turut, program itu akan dievaluasi keberadaannya, yang pada akhirnya membuat peniliaian team produksi program tersebut menjadi jelek. Oleh karena itu, setiap minggu catatan evaluasi team produksi Program OVJ Trans7 menjadi catatan untuk diusulkan tema atau topik yang akan dibahas untuk tayangan program OVJ selanjutnya.

\section{SIMPULAN}

Program Acara Komedi Operan Van Java dapat disimpulkan meraih sukses, karena berbagai manajemen komunikasi yang dilancarkan oleh manajemen stasiun TV Trans7. Manajemen komunikasi Trans7 pada program komedi televisi ditunjukkan dengan profesional dalam mengelola program komedi, membangun sinergi/kinerja semua kru untuk mengkomunikasikan ide-ide kreatif dan gagasan, menyamakan persepsi, mengemas pesan dan kesan sehingga menciptakan produk yaitu program OVJ yang menarik untuk penonton dan pesannya sampai ke penonton semua kalangan dan semua umur, sehingga OVJ tetap menduduki posisi pertama dalam rating acara sejenisnya kategori komedian.

Komedian merupakan saluran yang masuk secara langsung ke dalam psikologi seorang penonton, tentu memiliki sebuah pengaruh yang sangat besar, terutama anak-anak remaja. Karena itu peneliti menyarakan agar memperhatikan kata-kata, perilaku dan semua sisi lawakan komedi tersebut, agar generasi bangsa tidak terseret arus perilaku tersebut. Disarankan kepada manajemen OVJ, agar memilih topik-topik hangat yang berhubungan dengan isu yang sedang hangat dan fenomenal, dan harus menyisipkan pesanpesan moral kepada masyarakat pemirsa televisi. Tentu tidak ada kerugian dari sisi manajemen, bahkan justru semakin membuat program komedi OVJ ini meningkat dan memenangkan persaingan.

\section{DAFTAR PUSTAKA}

Baksin, Askurifal, Jurnalistik Televisi; Teori dan Praktek, Simbiosa Rekatama, Bandung 2009.

Baran, J. Stanley \& Dennis K. Davis; Teori Komunikasi Massa; Dasar, Pergolakan dan Masa Depan, Penerbit Salemba Humanika, 2010.

Burton, Graeme.2000. Membincangkan Televisi: Sebuah Pengantar Kepada Kajian Televisi;Jalasutra, Yogyakarta.

Himantoro, Guritno, Strategi Media Grup Nusantara Citra Dalam Menyikapi Penerapan Sistem Televisi Berjaringan, Tesis Universitas Mercua Buana, Jakarta, 2009. 
Komisi Penyiaran Indonesia (KPI), Pedoman Perilaku Penyiaran dan Standar Program Siaran (P3SPS Tahun 2004, 2007, 2010),Jakarta.

Lembaran Negara Republik Indonesia Nomor 4252, Undang-Undang Republik Indonesia Nomor 32 Tahun 2002, Jakarta.

Lull, James. 1998. Media, Komunikasi, Kebudayaan: Suatu Pendekatan Global; Yayasan Obor Indonesia, Jakarta.

Miles Matthew B \& A. Michael Huberman; Analisis Data Kualitatif, Penerbit Universitas Indonesia, 1992

Miles, M.B. \& A.M. Huberman (1984) Qualitative Data Analysis: A source book for new methods. Beverly Hills CA: Sage Publication Inc

Neuman, W. Laurance Social Research Methodes, Qualitative and Quantitative Approaches, hal 83

Sainuddin, Strategi Produksi Dalam Rangka Meningkatkan Kualitas Program Acara Televisi (Studi Deskriptif Tentang Program Feature Dokumentasi Situs-Situs di Lembaga Penyiaran Publik TVRI Pusat), Tesis Universitas Mercua Buana, Jakarta, 2010.

Severin, Werner J. \& James W. Tankard; Teori Komunikasi, Sejarah, Metode dan Terapan di Dalam Mediia Massa, Kencana, Jakarta 2008

Data ONLINE; 2010 : AGB Nielsen Peoplemeter Technology, Januari http://agbnielsen.net diakses 